\section{POOLED RESOURCES}

\section{A mutually beneficial collaboration between a water company and a small applied science university yields an innovative and sustainable treatment.}

\section{BY JACK LEEMING}

S evern Trent, one of the United Kingdom's 32 privately owned water companies, decided in 2009 to move to a more open innovation model instead of relying entirely on in-house research and development.

The postgraduate-only Cranfield University in Bedfordshire, with engineering consultancy Atkins, won the tender for the outsourced portion of Severn Trent's R\&D (Atkins later left the partnership). A long history of private-sector collaboration, a highly regarded water science institute, and existing links to Severn Trent worked in Cranfield's favour. In return for covering the costs of research including personnel, Severn Trent had input into steering research aligned with commercial goals.

Academic and industry collaborations are common in the water sector. The Cranfield and Severn Trent partnership was among the top 100 global corporate-academic partnerships in Earth and environmental sciences, according to the Nature Index, with half of the top 20 collaborations involving water companies. Partnerships are ongoing in Portugal, Germany, Australia and the United States.

Such collaborations are set to become more important, as populations, especially in cities, increase and water shortages loom due to global warming. The 2014 Intergovernmental Panel on Climate Change's Fifth Assessment Report said climate change would reduce renewable surface water and groundwater resources significantly in dry, subtropical regions. Droughts would increase in dry regions, while heavy rainfall and floods elsewhere will undermine drinking water quality, even with conventional treatment, the report said.

\section{CRITICAL QUESTIONS}

Peter Fiske, who runs the Water-Energy Resilience Research Institute at the Lawrence Berkeley National Laboratory, says emerging economies in particular are facing critical questions about water cycle sustainability. "Emerging cities in Africa, for example, won't be able to retrofit an existing city with a centralized treatment system," says Fiske. The search for solutions provides an opportunity for powerful research collaborations between academia and the corporate sector, he says. "Water facilities are sitting on a wealth of data and complex process experience. But they often lack the ability to fund even rudimentary exploration of how their processes can be optimized."
The Cranfield-Severn Trent partnership has brought a variety of university-developed technologies into the water treatment facilities. The company's new algae-based treatment system, in Packington, in the Midlands of England, is one example. Stringent legal limits on phosphorus content in wastewater had been a challenge for Severn Trent. The usual ways of complying with those limits "involve dosing with lots of chemicals and using quite a lot of energy. It's not particularly sustainable," says Peter Vale, who leads Severn Trent's innovation work.

Cranfield's researchers suggested using the digestive capacity of naturally occurring algae to clean phosphorus from the water, a method commonly used in more temperate climates. To make this natural filtration work in the UK, Cranfield's scientists engineered tiny, dense spheres of algae held together with alginate, the same material that makes up cell walls.

The resulting beads sink further and faster into wastewater than natural algae, and can be easily sieved out. This innovation allowed Severn Trent to develop a more intensive process than the algae ponds used in warmer countries. The beads can be digested by Severn Trent's existing facilities and converted into energy.

Yadira Bajón Fernández, an academic at Cranfield who has worked with Severn Trent since 2014, says that she can see the advantages of the collaboration from both sides: while Severn Trent gets the skills and innovation of academia, she and other academics get to see their research flow out of a journal and into practical use. "To have a direct impact on the way water is delivered to people - that's really satisfying," says Bajón Fernández. 